\title{
Structural static and modal frequency simulations in a coffee harvester's chassis
}

\author{
Evandro P. da Silva ${ }^{1}$, Fábio M. da Silva ${ }^{1}$, Ednilton T. de Andrade ${ }^{1} \&$ Ricardo R. Magalhães $^{1}$ \\ ${ }^{1}$ Universidade Federal de Lavras/Departamento de Engenharia Agrícola. Lavras, MG. E-mail: evandrosilva@posgrad.ufla.br (Corresponding author) \\ - ORCID: 0000-0002-5312-6657; famsilva@prpg.ufla.br - ORCID: 0000-0002-6367-5422; ednilton@deg.ufla.br - ORCID: 0000-0002-8448-8781; \\ ricardorm@deg.ufla.br - ORCID: 0000-0002-1946-1101
}

\section{Key words: \\ design \\ vibration \\ resonance \\ stresses \\ displacements}

\begin{abstract}
A B S T R A C T
Coffee harvesters are subject to stresses and vibrations in their structure, originating from engines and harvesting system. These structures must be designed to avoid rupturing of the components due to fragility of the materials, inadequate geometries, or the phenomenon of resonance, which increases the displacements/deformations of the components. In this scenario, the main objective of this study is to analyse the results of stresses and displacements from two static simulations and to present results of natural vibration frequencies from two modal simulations in a self-propelled coffee harvester. For this purpose, 20 modal shapes were generated, considering coffee harvester reservoir as empty and full. The simulations were carried out using the finite element method in which actual boundary conditions were applied to the motor chassis of the harvester. As results, stresses above the material's yield strength were observed in some regions of the components. Greater displacements were observed at the rear of the chassis, suggesting a new positioning of the rear wheel to obtain a uniform load distribution. Some natural frequencies, which presented greater displacements/deformations, can be affected by the operation of the main motor, also associated with the vibrating system in the coffee harvest, which may cause rupture of components.
\end{abstract}

\section{Palavras-chave: \\ projeto \\ vibração \\ ressonância \\ tensões \\ deslocamentos}

\section{Simulações estrutural estática e de frequências modais no chassi de uma colhedora de café}

\section{R E S U M O}

As colhedoras de café estão sujeitas a esforços e vibrações em sua estrutura, oriundos de motores e do sistema de derriça de café. Estas estruturas devem ser projetadas de modo a evitar ruptura dos componentes, em razão da fragilidade dos materiais, geometrias inadequadas, ou pelo fenômeno de ressonância, o qual amplia os deslocamentos/deformações dos componentes. Neste cenário, objetivou-se com o presente trabalho analisar resultados de tensões e deslocamentos provenientes de duas simulações estáticas e apresentar resultados de frequências naturais de vibração de duas simulações modais em uma colhedora de café automotriz. Para este fim, geraram-se 20 formas modais, considerando o reservatório da colhedora vazio e cheio de café. As simulações foram realizadas pelo método dos elementos finitos em que foram aplicadas condições de contorno reais no chassi motor da colhedora. Como resultados, observaram-se regiões dos componentes com tensões acima do limite de escoamento do material. Verificaram-se também, na parte traseira do chassi, maiores deslocamentos, o que sugere novo posicionamento da roda traseira para obtenção de distribuição uniforme das cargas. Algumas frequências naturais, que apresentaram maiores deslocamentos/deformações, podem ser atingidas pelo funcionamento do motor principal associado também ao sistema de vibradores na derriça do café, podendo causar ruptura de componentes. 


\section{INTRODUCTION}

Self-propelled coffee harvesters are complex machines which involve several structural assemblies. In the design of this type of machine, its components undergo stresses and vibrations. According to Ferraz et al. (2012) and Ferreira Júnior et al. (2016), vibrations are parameters that influence coffee harvest efficiency. This context justifies the importance of a design involving forces and vibrations. Niemczewski et al. (2014) claim that simulations using the finite element method help structural, thermal and vibration designs in pieces of varied shapes. For Leake \& Borgerson (2015), this method is based on the relationship between stress and deformation of a material and can represent actual situations occurred in the field, possibly reducing design time and costs with prototypes. He et al. (2010), Petracconi et al. (2010), Yildiz \& Duzgun (2010), Castillo \& Cruchaga (2012), Magalhães et al. (2012) and Figueiredo et al. (2016) presented several applications of the technique with experimental results. Important results were obtained in agricultural engineering using structural simulations, such as in Magalhães et al. (2006), Celik et al. (2011), Nilnont et al. (2012), Li et al. (2013), Oliveira et al. (2014), Silva et al. (2014) and Hernandez et al. (2016), and also in studies on vibration conducted by Pinho et al. (2014) and Almeida et al. (2015).

This study mainly aimed to analyse part of the structure of a coffee harvester, specifically its motor chassis, through static structural simulations, generating results of von Mises stresses, total deformations and total frequency simulations, determining natural vibration frequencies, associating to each frequency the results of total deformation. Based on the obtained results, we aimed to verify whether the structure withstood external stresses and whether the resonance phenomenon occurred.

\section{Material AND Methods}

The study was carried out at the Laboratory of Informatics of the Department of Agricultural Engineering of the Federal University of Lavras, from April to May 2017, whereas the test of harvest in the field was conducted in June 2017 in the city of Araxá, MG, Brazil (19³7’33.8” S; 46 56’ 45.6” W).

First, the main structural components employed in the design of self-propelled coffee harvesters used in the market were evaluated. In this step, data such as the following were collected: type and shape of materials used in the structure, such as 1020 steel, ASTM A36 steel, square tubes, round tubes, plates, structural distribution of these materials in the harvester, number of wheels, heights, widths and lengths, vibration frequencies of the coffee harvest cylinders, types of articulations, machine slopes, coffee storage systems, oil reservoirs, types of motors and their weights.

Then, the geometric model of the harvester's structural part was defined considering the revolution or redraw process, as described in Ashby et al. (2012).

The geometric model was developed in the commercial program Solid Works ${ }^{\varpi}$ and simulated in the program Ansys ${ }^{\oplus}$, after importing the geometry.
The next step was to define the types of simulations/studies based on criteria that illustrated the actual situation of use of the harvester's components in the field, which was performed using two types of simulation:

a) Structural static, to generate results of von Mises stresses and total deformations/displacements. According to Budynas \& Nisbett (2016), the von Mises failure criterion generates the results mentioned for ductile materials, known as distortion energy theory, when subject to static loadings, and considers that the von Mises stress, calculated for the components, should not be higher than the yield strength of the material. Yield strength is obtained by means of a tensile test and von Mises stress depends on the elasticity modulus, Poisson coefficient and density of the materials;

b) Modal frequency, using the matrix iterative method, which according to Rao (2009) determines various natural frequencies of vibration, starting from the lowest one, associating to each frequency the results of total displacement/ deformation. The results are generated according to the resolution of the equation which takes into consideration the nodal vectors of displacement, velocity, acceleration, force, besides the mass, damping and stiffness matrices.

Four variations of types of simulation were also considered, namely:

1 - Structural analysis with fully loaded coffee reservoir. 2 - Empty coffee reservoir: these analyses aimed to determine the von Mises stresses and displacements present in the components when subjected to forces caused by loadings, allowing to observe the points of highest stresses and displacements with maximum load. 3 - Modal analysis with full coffee reservoir; 4 - Empty coffee reservoir: this analysis aimed to determine displacements of components for pre-set natural frequencies of vibration, verifying the influence of the vibration frequencies on the components' displacements. Twenty modes of frequency $(\mathrm{Hz})$ were generated, highlighting the values close to the frequencies the machine motor can generate when it enters in resonance, which is a detrimental factor to the components of a structure and can cause large displacements and rupture.

The material used for the model was structural steel with density of $7850 \mathrm{~kg} \mathrm{~m}^{-3}$, yield strength of $2.5 \times 10^{8} \mathrm{~N} \mathrm{~m}^{-2}$ and ultimate tensile strength of $4.0 \times 10^{8} \mathrm{~N} \mathrm{~m}^{-2}$, based on the norm of structural materials ASTM A36.

Boundary conditions of loading were considered as forces from the weights of the adequately distributed components (Table 1), besides the specific weight, already calculated by the program, according to model geometry, associated with the density of the material used in the structure.

The weights described in Table 1 are distributed in the chassis of the evaluated model as shown in Figure 1.

Table 1. Weights of the coffee harvester's components

\begin{tabular}{lc}
\hline \multicolumn{1}{c}{ Component } & Weight (N) \\
\hline Main motor set & 6000 \\
Empty coffee reservoir & 4000 \\
Hydraulic oil tank and reservoir & 300 \\
Battery & 200 \\
Fuel tank & 5000 \\
Radiator & 500 \\
\hline
\end{tabular}




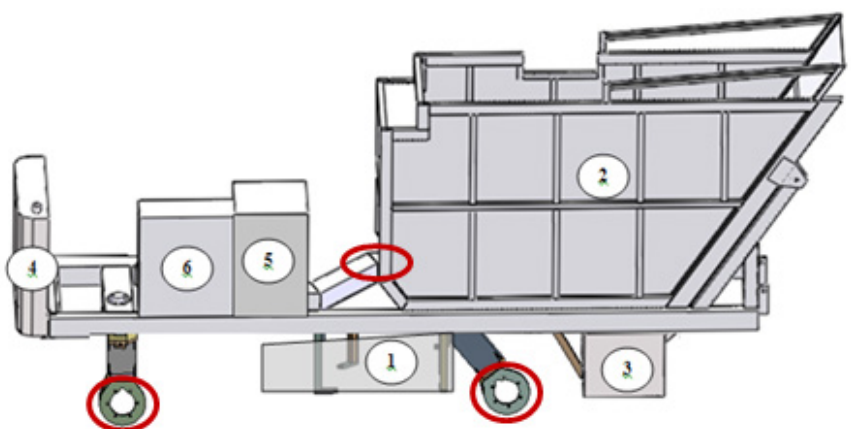

Figure 1. Evaluated model: 1 - Main motor set; 2 - Coffee reservoir; 3 - Battery; 4 - Oil reservoir; 5 - Fuel tank and 6 - Radiator

Boundary conditions were initially defined by fixing the structure in three regions highlighted in Figure 1. These regions correspond to the positions of two wheels and region of connection with the rest of the structure.

A mechanical grid was generated with triangular and squared regions which showed element sizes from 0.038 to 25 mm, with 216,914 nodes and 52,230 elements.

\section{Results AND Discussion}

The results of von Mises stress (MPa) calculated for the structural simulations with full and empty coffee reservoir are presented in Figures $2 \mathrm{~A}$ and B, respectively.

In both Figures $2 \mathrm{~A}$ and $\mathrm{B}$, it is possible to note that maximum von Mises stresses exceeded the material yield strength in the tensile test, which was $250 \mathrm{MPa}$. According to Chiaverini (2002), designs of a mechanical structure use a Safety Factor (SF), which is obtained by dividing between calculated stress and the resistance adopted for the material, which is the yield strength in the von Mises criterion. For Chiaverini (2002), safety factors vary according to the type of load, type of material and operating conditions and, for ductile materials, such as ASTM A36 carbon steel, the values range from 1.5 to 4.0. Considering the lowest value $(\mathrm{SF}=1.5$ ), maximum von Mises stress should not exceed 166.67 MPa, which did not occur in some regions in the tests with full and empty coffee reservoir, although the ultimate tensile strength of the material in the analyzed structure, $400 \mathrm{MPa}$, has not been reached in the test with empty coffee reservoir.

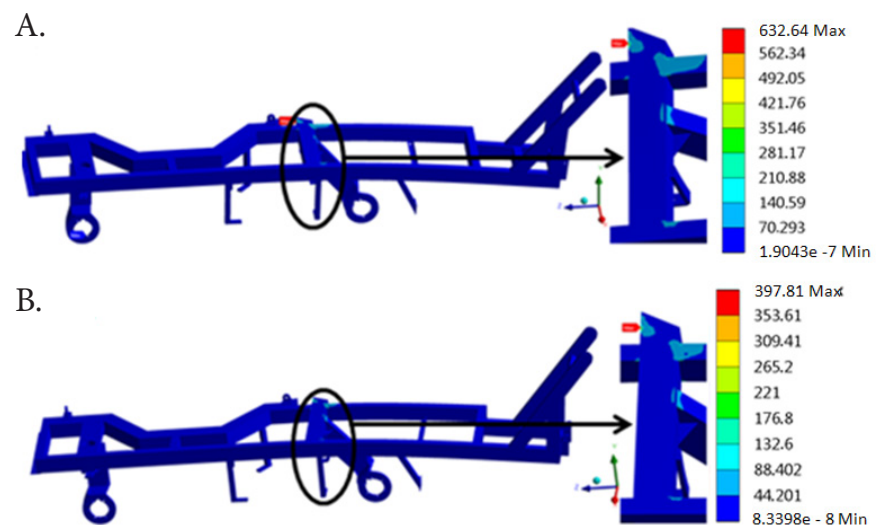

Figure 2. Results of von Mises stress (MPa) for full coffee reservoir $(\mathrm{A})$ and empty coffee reservoir (B)
The results of displacement ( $\mathrm{mm}$ ) for structural simulations with full and empty reservoir are presented in Figures $3 \mathrm{~A}$ and $B$, respectively.

According to Figures $3 \mathrm{~A}$ and $\mathrm{B}$, maximum displacements were found in the same region, considering both cases analysed (full and empty reservoir). There was a difference between the maximum values, $15.83 \mathrm{~mm}$ for the simulation with full reservoir and $9.20 \mathrm{~mm}$ for the simulation with empty reservoir. In both cases, the chassis tended to displace with higher intensity in the rear part. Thus, a new position of the wheels should be adopted to try to improve the distribution of loads and, consequently, reduce the maximum displacements.

The results of displacement $(\mathrm{mm})$ for the modal simulations with full and empty reservoir are presented in Figures 4A and $\mathrm{B}$, respectively.

Comparing the tests with full and empty reservoir, the frequencies of 37.6 and $37.8 \mathrm{~Hz}$ led to highest displacements.

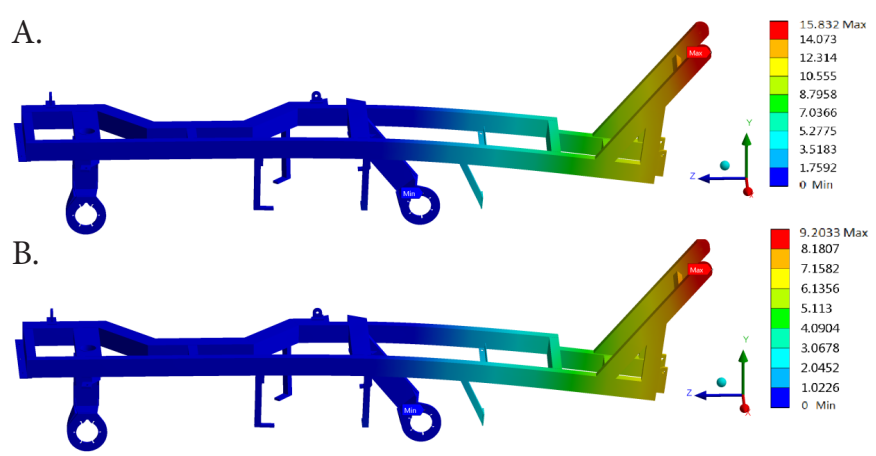

Figure 3. Results of displacements $(\mathrm{mm})$ for structural simulations with full coffee reservoir $(\mathrm{A})$ and empty coffee reservoir $(\mathrm{B})$
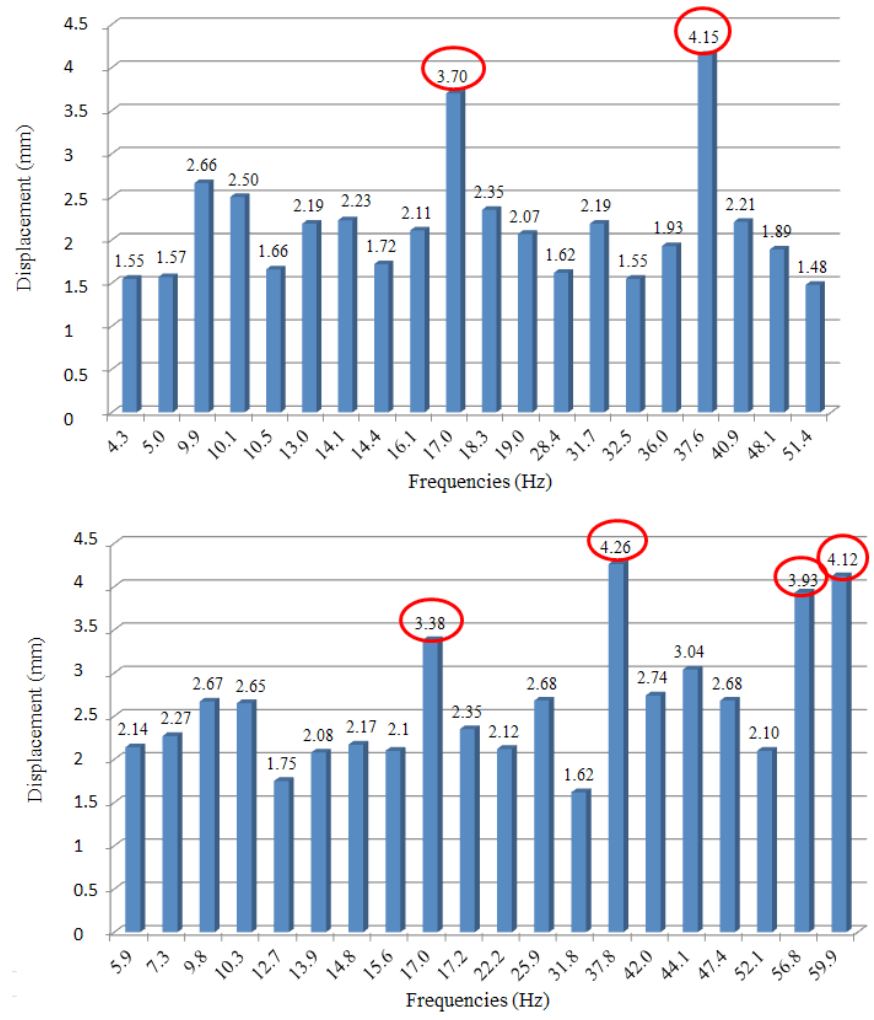

Figure 4. Results of displacement $(\mathrm{mm})$ for modal simulations with full coffee reservoir $(\mathrm{A})$ and empty coffee reservoir (B) 
The results were significant because several main motors of selfpropelled harvesters, according to the motor set manufacturer, operate at frequencies of 26.7, 30.0 and $33.3 \mathrm{~Hz}$, depending on the gear selected. Motor frequencies can be combined with the frequencies generated in the vibrating system of the cylinders, which vary among some models of harvesters from 11.0 to $17.0 \mathrm{~Hz}$ (Silva et al., 2006; Oliveira et al., 2007; Silva et al. 2013; Ferreira Júnior et al., 2016), possibly generating the phenomenon of resonance.

For Rao (2009), it is possible to reduce, but not eliminate, the dynamic forces which cause vibrations and the methods to control the vibrations can be: controlling the natural frequencies of the system; avoiding excessive response of the system, even in resonance, by using damping/energy dissipation mechanisms; using vibration isolators to reduce the transmission of forces between components; and alteration of mass and stiffness of the system, to change the natural frequencies.

The coffee harvester had vibration problems in the field, as shown in the simulations. The lower part of the chassis is presented in Figure 5, showing the motor set attached to the projected supports, before and after modifications and addition of components, highlighting the shear in the fastening screw of a component of the main motor.

Figure 5 presents the modifications made, such as the change from 30-mm-thick cushions to 50-mm-thick cushions. These cushions are responsible for connecting the motor to its supports with higher capacity to absorb vibration, and a total of 4 cushions were used in the harvester. In addition, the weight of the system increased, which is one of the factors that reduce forces that cause vibration according to Rao (2009). This was carried out by installing a gutter-like structure molded in a folded carbon steel plate. After the modifications (Figure 5), the machine was monitored for $50 \mathrm{~h}$ of operation in the field and no screws broke.



Figure 5. Lower part of the chassis with the attached motor set at 2 moments

\section{Conclusions}

1. Maximum von Mises stresses above the material's yield strength were found in some regions of the structure in two different structural static simulations (with full and empty coffee reservoir).
2. Displacements in the simulations were higher at the rear of the chassis, indicating an imbalance in the distribution of wheels in both structural simulations.

3. Both modal simulations showed higher values of displacement for some frequencies of vibration.

4. Frequencies caused by main motors of the harvesters and vibration cylinders can have isolated or combined values close to the frequencies that led to greatest displacements, causing the phenomenon of resonance, which is detrimental to the structure.

\section{ACKnowledgments}

To the Minas Gerais Research Support Foundation (FAPEMIG), for the financial support to the project.

To the company Vetor Indústrias de Máquinas LTDA, for making it possible to follow the machine's construction and operation.

\section{Literature Cited}

Almeida, S. F.; Abrahão, R. F.; Tereso, M. J. A. Avaliação da exposição ocupacional à vibração de corpo inteiro em máquinas de colheita florestal. Cerne, v.21, p.1-8, 2015. https://doi.org/10.1590/01047 760201521011446

Ashby, M. F.; Shercliff, H.; Cebon, D. Materiais: Engenharia, ciência, processamento e projeto. Rio de Janeiro: Elsevier, 2012. 650p.

Budynas, R. G.; Nisbett, J. K. Elementos de máquinas de Shigley: Projeto de engenharia mecânica. 10.ed. Porto Alegre: AMGH Editora, 2016. 1073p.

Castillo, E. F.; Cruchaga, M. A. Experimental vibration analysis for a 3D scaled model of a three-floor steel structure. Latin American Journal of Solids and Structures, v.9, p.597-613, 2012. https://doi. org/10.1590/S1679-78252012000500005

Celik, H. K.; Rennie, A. E. W.; Akinci, I. Deformation behaviour simulation of an apple under drop case by finite element method. Journal of Food Engineering, v.104, p.293-298, 2011. https://doi. org/10.1016/j.jfoodeng.2010.12.020

Chiaverini, V. Aços e ferros fundidos. 7.ed. São Paulo: Associação Brasileira de Metalurgia e Materiais, 2002. 561p.

Ferraz, G. A. e S.; Silva, F. M. da; Alves, M. de C.; Bueno, R. de L.; Costa, P. A. N. da. Geostatistical analysis of fruit yield and detachment force in coffee. Precision Agriculture, v.13, p.76-89, 2012. https:// doi.org/10.1007/s11119-011-9223-8

Ferreira Júnior, L. de G.; Silva, F. M. da; Ferreira, D. D.; Sales, R. S. Recommendation for mechanical harvesting of coffee based on vibration behavior settings rods harvesters. Ciência Rural, v.46, p.273-278, 2016. https://doi.org/10.1590/0103-8478cr20141679

Figueiredo, M. A. de M.; Silva, L. F; Barnabé, T. L. Transporte coletivo: Vibração de corpo-inteiro e conforto de passageiros, motoristas e cobradores. Journal of Transport Literature, v.10, p.35-39, 2016. https://doi.org/10.1590/2238-1031.jtl.v10n1a7

He, B. Y.; Wang, S. X.; Gao, F. Failure analysis of an automobile damper spring tower. Engineering Failure Analysis, v.17, p.498505, 2010. https://doi.org/10.1016/j.engfailanal.2009.09.010 
Hernandez, R. O.; Garcia, L. M. G.; Tinôco, I. de F. F.; Martins, J. H.; Souza, C. de F.; Saraz, J. A. O. Simulation of the internal environment of a post-harvest installation and a solar dryer of coffee. Revista Brasileira de Engenharia Agrícola e Ambiental, v.20, p.163-168, 2016. https://doi.org/10.1590/18071929/agriambi.v20n2p163-168

Leake, J. M.; Borgerson, J. L. Manual de desenho técnico para engenharia: Desenho, modelagem e visualização. 2.ed. Rio de Janeiro: LTC, 2015. 368p.

Li, Z.; Li, P.; Yang, H.; Liu, J. Internal mechanical damage prediction in tomato compression using multiscale finite element models. Journal of Food Engineering, v.116, p.639-647, 2013. https://doi. org/10.1016/j.jfoodeng.2013.01.016

Magalhães, A. C.; Teixeira, M. M.; Couto, S. M.; Resende, R. C. de. Modeling of pneumatic machine collector of coffee fruits on yard using finite elements analysis. Engenharia Agrícola, v.26, p.483492, 2006. https://doi.org/10.1590/S0100-69162006000200017

Magalhães, R. R.; Fontes, C. H.; Melo, S. A. B. V. de. Failure analysis and design of a front bumper using finite element method along with durability and rig tests. International Journal of Vehicle Design, v.60, p.71-83, 2012. https://doi.org/10.1504/ IJVD.2012.049158

Niemczewski, B. K.; Reis, A. V. dos; Machado, R. L. T.; Machado, A. L. T. Validação de um modelo de cálculo por elementos finitos do chassi de uma semeadora de quatro linhas. Engenharia Agrícola, v.34, p.161-170, 2014. https://doi.org/10.1590/S010069162014000100017

Nilnont, W.; Thepa, S.; Janjai, S.; Kasayapanand, N.; Thamrongmas, C.; Bala, B. K. Finite element simulation for coffee (Coffea arabica) drying. Food and Bioproducts Processing, v.90, p.341-350, 2012. https://doi.org/10.1016/j.fbp.2011.06.007
Oliveira, E. de; Silva, F. M. da; Salvador, N.; Figueiredo, C. A. P. Influência da vibração das hastes e da velocidade de deslocamento da colhedora no processo de colheita mecanizada do café. Engenharia Agrícola, v.27, p.714-721, 2007. https://doi. org/10.1590/S0100-69162007000400014

Oliveira, M. V. M. de; Teixeira, M. M.; Fernandes, H. C.; Queiroz, D. M. de; Moreira, R. M. G. Computer-aided design of a coffeedragging device. Semina: Ciências Agrárias, v.35, p.2373-2382, 2014. https://doi.org/10.5433/1679-0359.2014v35n5p2373

Petracconi, C. L.; Ferreira, S. E.; Palma, E. S. Fatigue life simulation of a rear tow hook assembly of a passenger car. Engineering Failure Analysis, v.17, p.455-463, 2010. https://doi.org/10.1016/j. engfailanal.2009.09.002

Pinho, M. da S.; Schlosser, J. F.; Frantz, U. G.; Rodrigues, F. A.; Ferrer, P. S. Efetividade de um coxim de cabina do trator agrícola na atenuação das vibrações. Revista Ciência Agronômica, v.45, p.461468, 2014. https://doi.org/10.1590/S1806-66902014000300005

Rao, S. S. Vibrações mecânicas. 4.ed. São Paulo: Pearson Education do Brasil, 2009. 424p.

Silva, E. P. da; Silva, F. M. da; Magalhães, R. R. Application of finite elements method for structural analysis in a coffee harvester. Engineering, v.6, p.138-147, 2014. https://doi.org/10.4236/eng.2014.63017

Silva, F. C. da; Silva, F. M. da; Silva, A. C. da; Barros, M. M. de; Palma, M. A. Z. Desempenho operacional da colheita mecanizada e seletiva do café em função da força de desprendimento dos frutos. Coffee Science, v.8, p.53-60, 2013.

Silva, F. M. da; Oliveira, E. de; Guimarães, R. J.; Figueiredo, C. A. P. de; Silva, F. C. da. Desempenho operacional e econômico da derriça do café com uso da derriçadeira lateral. Coffee Science, v.1, p.119-125, 2006.

Yildiz, Y.; Duzgun, M. Stress analysis of ventilated brake discs using the finite element method. International Journal of Automotive Technology, v.11, p.133-138, 2010. https://doi.org/10.1007/ s12239-010-0018-0 